\title{
REVIEW
}

\section{Steven Leonard Jacob, editor Confronting Genocide: Judaism, Christianity, Islam}

(Lanham: Lexington Books, 2009), paperback, xvii + 343 pp.

Björn Krondorfer, St. Mary's College of Maryland

The continuously growing literature on genocide-both in the form of anthologies and monographs-is often comparative in scope, looking at various genocides from different historical and geographical locations and through particular frames of reference. For example, in 2009, when the book under review was published, two other works appeared: Cathie Carmichael's Genocide Before the Holocaust, which argues that genocidal conflicts before the Holocaust (especially the Balkan wars) were the result of collapsing empires (Austro-Hungarian and Ottoman) and the rise of nationalism, and Allan Cooper's The Geography of Genocide, which applies a feminist analysis of masculine ideologies that characterize perpetrators of different genocides. With respect to anthologies, the 2004 volume Century of Genocides (edited by Samuel Totten, Williams S. Parsons, and Israel W. Charny) and the 2002 volume In God's Name: Genocide and Religion and the Twentieth Century (edited by Omer Bartov and Phyllis Mack) can be mentioned as points of comparison to Steven Jacob's Confronting Genocide. Whereas Totten, Parsons, and Charny pay hardly any attention to religion because they look at genocide from the perspectives of the historical, social, and political sciences, Bartov and Mack address religion but remain primarily focused on the Holocaust.

Jacob's new anthology aims at a middle path: it wants to engage the "all-too-prominent role of religion in [the] horror" of genocidal atrocities, beyond the more usual Jewish and Christian responses to the Holocaust (p. x). Hence, the eighteen chapters (all except two were written especially for this volume) cover genocides against Rwandans, Armenians, Bangladeshis, Native Americans, residents of the former Yugoslavia, and Jews during the Holocaust.

Focusing on the link between genocide and the three Abrahamic traditions is a sensible way of working within a compatible set of interpretive frames, such as monotheism, messianism, eschatology, shared textual traditions, or simply the intimately tense relations between Jews, Christians, and Muslims throughout history. Such a focus, of course, explains why there are no chapters on genocides in Timor or Cambodia (which, for example, are included in Totten's Century of Genocide).

The role of religion in genocide was previously addressed in two seminal essays by Leo Kuper ("Theological Warrants for Genocide: Judaism, Islam, Christianity" from 1990) and Leonard Glick ("Religion and Genocide" from 1994). They have both argued for the genocidal potential inherent in the Jewish, Christian, and Muslim traditions. Their inclusion here is valuable. Kuper argues that differences in religious belief have served as legitimizing ideologies (though not "in isolation from the societal context" [p. 26]); Glick similarly states that religious differences "impel people...to perpetrate genocidal crimes" and that it is in the human "evolutionary heritage...to dislike [and] to distrust" other people. Religions, far from helping to overcome this dislike of others, "are part of the problem." Hence, "religious leaders, whether they be shamans, priests, pastors, mullahs, or rabbis, appear on the average to demonstrate neither more nor less compassion for 
aliens than anyone else" (p. 113). The problem with Kuper's and Glick's analyses is that they remain general and unspecific, painting a picture of religion in rather broad strokes. Not surprisingly, some contributors, such as Zev Garber and David Patterson, take issue with Kuper's and Glick's limited understandings of Judaism and Christianity.

The articles by Kuper and Glick are also somewhat dated. This is particularly obvious in the case of Kuper (1908-1994), who relies on sources published in the 1970s and early 1980s. His section on Christianity, for example, repeatedly refers to Rosemary Radford Ruether's Faith and Fratricide (1974) and The Wrath of Jonah (1989, co-authored with Herman Ruether); his section on Islam relies heavily on Bernard Lewis, the famous Princeton Orientalist, also known as "an unapologetic foreign policy hawk" (New York Review of Books, April 7, 2011, p. 83).

Nevertheless, Kuper and Glick serve as anchors around which the contributions are organized. Formally separated into four parts, Confronting Genocide begins with a section that probes the role of biblical narratives and, to a lesser degree, liturgical recitations and traditions in legitimating and motivating genocidal mentalities. Part II explores the religion-genocide link through case studies of Armenia, Bangladesh, Rwanda, and the Balkans, and it is here that we find the widest angle in comparative genocide studies. Parts III and IV are quite similar in their overall thematic approach, probing troubling texts in the Bible (III) and troubling theologies in Judaism and in the Christian churches (IV). Here, the contributors use the Holocaust as the main matrix for their reflections, with the notable exception of Carol Rittner. Rittner, who is the only female contributor to this volume, fiercely laments the Catholic Church's silence vis-à-vis rape and sexual violence against women in Rwanda and the former Yugoslavia.

The narrowing of perspective in Parts III and IV is somewhat unfortunate, given the title and intention of this anthology. Not only does Confronting Genocide return to the Holocaust as the kind of paradigmatic event that shapes our thinking about Judaism and Christianity, it also limits itself to a particular cohort of thinkers, who-despite the scholarly merit and academic recognition their work deserves - think too much alike since they have been in conversation with each other for decades. They include Richard Rubinstein, Donald Dietrich, John Pawlikowski, John Roth, Zev Garber, Henry Knight, Steven Jacobs, James Moore, and Carol Rittner. One misses the voices of a younger generation of scholars.

Although the subtitle of Confronting Genocide prominently and promisingly mentions Islam as the third Abrahamic religion to be covered, readers may be disappointed by the dearth of attention to this subject. Mohammad Omar Farooq, who is from Bangladesh and writes about the genocide there in 1971, is the only contributor from an Islamic background; however, Farooq is not a religious studies scholar but a professor of economics (at Upper lowa University). Two other contributors mention Islam in somewhat more sustained ways, but both give it a decidedly negative reading. Richard Rubenstein, who probes religious motivation behind the Turkish killings of Armenians, presents the concepts of dar al-harb (region of war), dhimmi (the special status of Jews and Christians in Islamic empires), and jihad in a most ungenerous way, concluding that, "strictly speaking, Islamic tradition envisages no such thing as genuine peace between faithful Muslims and infidels" (p. 124). Rubinstein, like Kuper, relies heavily on Bernard Lewis' work on Islam. David Patterson, who argues theologically that genocides have emerged in modernity because of the loss of a divine absolute in the European Enlightenment, also sees nothing good in Islam. Qur'anic sources, he argues, do not reveal counterweights to power; hence, "in modern times, at least, the Muslim world has produced no one comparable to Mahatma Gandhi or Martin Luther King, Jr. What that world has produced is a discourse of rabid Jewhatred, a notion of martyrdom defined in terms of murder, and an international network of 
terrorism" (p. 205). The growing literature on Islam and democracy and Islam and human rights is, it seems, willfully ignored.

Many of the contributions do not present primary research but build their arguments upon secondary literature. In itself, there is nothing wrong with such an approach as long as one analyzes the existent literature for how it takes account (or fails to take account) of religious motives and motivations, or if one aims at ethical and theological reasoning on the basis of available publications. In the case of Confronting Genocide, the lack of primary research has led to a loss of originality in some chapters. For example, too many contributors adopt Rwanda as their case study, without adding too much new insight. James Moore, Stephen Haynes, Paul Bartrop, Donald Dietrich, John Pawlikowski, and Carol Rittner refer to Rwanda, but not a single entry addresses Sudan, Darfur, the Congo, or the use of child soldiers in mass atrocities. Moore's chapter on the culpability of Christian churches in Rwanda is especially problematic. Claiming that liturgical texts (especially Easter hymns) contribute to the justification of genocidal killings, Moore repeatedly states that his "analysis is purely suggestive" (p. 71) and "hypothetical" (p. 74), that "evidence is scant" (p. 70), and that more "empirical research" needs to be done (p. 75). Twice in his footnotes he feels the need to explain what his point is not (it is "not" to show "exactly how the churches were involved" [p. 75 n. 6] or to "demonstrate that the Rwandan genocide was...impacted directly by the theology of the churches in Rwanda" [p. 76 n. 8]). He cites hymns of American Protestant churches at length but admits that he had no "access to the additional liturgical texts that were used" at the Easter celebrations in Rwanda four days before the organized killing spree that started in April 1994. His chapter is based on conjectures and speculations but, as we know, these neither can count for evidence nor can replace a scholarly thesis. Stephen Haynes' essay on Rwanda, on the other hand, makes good use of the secondary literature in pondering how problematic it is to relate the events in Rwanda to the Holocaust. Any attempt at easy comparison might fail to account for the racial dimension of the African genocide, for the relatively swift arrest of Hutu perpetrators (Christian clergy among them), and for the general difficulty that white Christians have when including Africa on their religious and "mental map" (p. 190).

In addition to Haynes and Rittner, other chapters are worth the purchase of the book: Paul Mojzes' excellent explanation of the Balkan wars and the differences between ethnic cleansing and genocide (Mojzes, though, has little to say about religion); Henry Knight's midrashic play with biblical Amalek as the mythological figure of irredeemable evil; Gary Phillip's analysis of the links between national trauma, religion, and atrocities in the case of Kosovo; and John Pawlikowski's critical appraisal of Catholic social teaching on the Holocaust and the lack thereof with respect to genocide. Several chapters, however, are missing notable new insights. Donald Dietrich's piece on the Holocaust and the Catholic Church, for example, is a mosaic of short reflections on Nostra Aetate and Johannes Metz's thought (as read through Sarah Pinnock's work), followed by a short appeal to the Church to take responsibility in Rwanda and a brief summary of Robert Schreiter's work on reconciliation. Zev Garber's chapter on "Terror Out of Zion" offers a brief analysis of (mis)appropriations of biblical prooftexts to support Zionist claims, but the case study he offers on Rabin's assassination has been published previously. Chris Mato Nunpa's chapter on the genocide of Native Americans is, unfortunately, not so much an argument as a pastiche of various "scripture related" (p. 47) quotations that illustrate the racism and colonialist attitudes of white (Christian) people in their encounters with the indigenous population in the United States.

There are minor editorial slips, such as double entries for the same reference (e.g., Bruce Johansen, Ecocide [p. 62] or Bat Ye'or, The Decline [p. 136]). Also, a final updating on current events might have been good: the accused war criminal Radovan Karadzic, for example, is still 
listed as a fugitive, when, as a matter of fact, he was arrested in July 2008, a year before the anthology was published (p. 173).

In sum, Confronting Genocide contains a number of very good chapters, but this reviewer wishes the anthology had identified a broader spectrum of contributors among religious studies scholars and theologians, applied a more rigorous standard for accepting submissions, and included more up-to-date primary scholarship on geographically more widely spread genocides. 